\title{
LOS RASTROS DEL CANTO: LA PRODUCCIÓN POÉTICA DE LAUREANO ALBÁN
}

\author{
SINGING TRACES: \\ POETIC PRODUCTION OF LAUREANO ALBÁN **
}

Ronald Campos López*

\begin{abstract}
RESUMEN
En este artículo se compila el estado de la cuestión sobre la producción lírica del poeta costarricense Laureano Albán; así como las principales críticas sus textos y su papel dentro de la historiografía literaria costarricense. Palabras clave: Literatura costarricense, historiografía, crítica, poesía, Albán Laureano
\end{abstract}

\begin{abstract}
This article compiles all of the related issues about Costa Rican poet Laureano Albán's lyric production; as well as the main critics of his texts and his role at Costa Rican literature.

Key Words: Costa Rican literature, historiography, critic, poetry, Albán Laureano
\end{abstract}

Universidad de Costa Rica, Universidad Internacional de las Américas e Instituto de Educación Integral. Costa Rica.

** Traducción: Geannette Soto. Escuela de Lenguas Modernas, Universidad de Costa Rica.

Correo electrónico: ronaldc184@yahoo.com

Recepción: 24/01/13. Aceptación: 20/03/13. 


\section{Consideraciones generales sobre la producción poética de Laureano Albán}

La práctica poética ${ }^{1}$ de Laureano Albán ${ }^{2}$, "uno dei più importante poeti ispanoamericani contemporanei" "Pieragnolo, 2011: solapa del libro), ha sido analizada, de manera parcial, pues la crítica e historiografía costarricenses se han centrado en la producción albaniana desde 1966 hasta 1984. Grosso modo, en los análisis encontrados se insiste en una aproximación crítica o valorativa pertinente a textos, cuyas tendencias estético-ideológicas se orientan hacia las temáticas sociopolíticas de su primera etapa poética (Monge, 1984), principalmente; y, en segunda instancia, en temáticas existenciales generales. Casi no se ha profundizado en su poética de corte metafísico y sagrado.

Albán ha sido ubicado en diferentes generaciones con base en un marco de múltiples discrepancias y congruencias, a partir de un análisis de las principales fuentes historiográficas sobre la literatura y poesía costarricenses. Un grupo de críticos ha caracterizado su producción poética de acuerdo con aspectos otorgados a estas generaciones, principalmente ubicabas entre la década de los años sesenta y setenta; por ejemplo, cuando se alude a la génesis del Círculo de Poetas Costarricenses, a partir del Grupo de Poetas Turrialbeños, con lo cual se ratifica el papel fundante, ideológico y dirigente de Albán (Duverrán 1973, Baeza 1978, Monge 1981, Bonilla 1981, Chávez 1984, Monge 1984, Camacho 1987, Monge 1992, Rojas y Ovares 1995, Quesada 2000, Salas 2000, Durán 2003, Corrales 2007, Soto 2009).

Existen artículos y notas periodísticas sobre la producción poética albaniana; no obstante, una cantidad considerable corresponde a juicios impresionistas o a invectivas, cuyos comentarios se fundamentan en aspectos de la figura personal del poeta, antes que en criterios meramente literarios y críticos de los textos poéticos en $\mathrm{si}^{4}$. Por lo tanto, para efectos de este estudio, se excluye dicho corpus documental.

En consecuencia, los criterios, sobre los cuales Picado (1983) sistematizó la crítica literaria, se ajustan a las lecturas existentes sobre la producción poética albaniana, de la siguiente manera:

a) Clasificación de la producción lírica: Se ubican los textos albanianos y se regularizan sus lecturas a partir de la pertenencia del autor a una $\mathrm{u}$ otra generación.

b) Referencialidad biográfica de la temática: Corresponde a los artículos invectivos sobre la persona del poeta, los cuales abandonan la exclusividad textual.

c) Temática o tópico del texto: Se orientan a estudios críticos y parciales sobre la primera producción poética de Albán, relativa a su poesía de carácter social.

d) Composición formal del texto: $\mathrm{Se}$ redactan estudios u observaciones teóricas respecto de la utilización de ciertas estructuras tradicionales, como el soneto, y su resignificación, de acuerdo con las temáticas y perspectivas ideológicas abordadas por Albán durante su primera fase, principalmente en Sonetos laborales (1977) y Sonetos cotidianos (1978).

e) El proyecto ideológico del escritor: $\mathrm{Se}$ establece una exclusividad o tendencia de crear un panorama temático-ideológico a partir de aquellos textos albanianos correspondientes a una "poesía social"; se excluye así parte de la producción metafísica y arquetípico-simbólica, a pesar de los estudios sobre el discurso religioso y mítico en la poesía albaniana.

\section{Desde la historiografía literaria costarricense: Las generaciones literarias y Laureano Albán}

En la cuarta edición (1981) del texto Historia de la literatura costarricense, apenas si se menciona a Albán. Bonilla se refiere a él como miembro del grupo "Los Poetas de Turrialba", al 
cual caracteriza como tradicional, a pesar de la evolución de algunos de sus integrantes hacia motivos políticos y el abandono del "poema por el panfleto" (1981: 348). Sin embargo, no enfatiza críticas ni comentarios sobre Albán o cualquier otro poeta, pues un criterio de edad rige su investigación: Aduce que, por ser menores de treinta años, existe peligro de predicciones o poca seriedad respecto de sus labores poéticas, hasta ese momento histórico.

Si bien Bonilla ubica a Albán dentro de una generación conformada, principalmente, por Marco Aguilar, Manuel Calderón, Julieta Dobles, Jorge Debravo y Alfonso Chase; Quesada (2000) lo ubica como copartícipe de una segunda promoción de poetas, posterior al Gobierno de la Segunda República de Costa Rica, al lado de Jorge Debravo, Alfonso Chase, Mayra Jiménez, Rodrigo Quirós y Carlos de la Ossa. Por su parte, Rojas y Ovares (1995) comparten esta última ubicación generacional, exceptuando a De la Ossa, pero sumando a Julieta Dobles y Leonor Garnier. Sánchez (2011) comparte la descripción de Quesada (2000) y agrega a Rosa Kalina, Elliette Ramírez, Juan Antillón, Martha Royo, Germán Salas y Marco Aguilar; ellos, junto a Albán, conforman la primera postvanguardia, pues nacieron entre 1935 y 1949.

Según Quesada (2000), este segundo grupo se nutrió y desarrolló, entre 1960 y 1970, alrededor de acontecimientos socioculturales, políticos y económicos tales como: la Revolución Cubana, su ideología anticolonialista y antiimperialista; el surgimiento de nuevas tendencias culturales ("pop", "hippies", "beatniks"), las rebeliones estudiantiles y juveniles en contra de una educación, moral $\mathrm{y}$ orden social tradicionales. Tales hechos orientaron las producciones poéticas de estos autores en dos vertientes estético-ideológicas, intrincadas y cambiantes: Por un lado, una subjetiva, hermética y autorreferencial; por otro, una preocupada por lo social y la denuncia como transformación histórica. Esta última privaría en el grupo de Albán y sus contemporáneos, quienes evidenciaron ideas revolucionarias, incorporación de recursos de estéticas modernas distantes de las producciones tradicionales en el país, uso de un lenguaje simplificado y prosaico en algunos casos, así como una preocupación espiritual y existencial. En fin, una generación caracterizada por una búsqueda ampliamente heterogénea, novedosa, experimental y crítica de la retórica, el hermetismo, la poesía convencional y los valores de un contexto nacional decadente.

Estos argumentos coinciden con los expuestos por Monge (1992), quien sitúa a Albán en el tercer movimiento vanguardista o primer postvanguardista nacional. Dicha generación es integrada por los poetas nacidos entre 1938 y 1948. Concuerda con los criterios de Bonilla (1981) y Quesada (2000) al incluir a Debravo, Jiménez, Dobles, Aguilar, Chase, Quirós y De la Ossa; al tiempo que suma a Salas, Kalina Antillón (tal como Sánchez 2011) y Guillermo Sáenz. Según Monge, este grupo presenta: “una obsesión por romper con los límites de nuestra tradición poética; [en donde Albán] apareció como una nueva respiración que buscaba un nuevo tono a la lírica costarricense desde su propia realidad" (1984: 46). Si bien, "para esta generación el mundo es una realidad política, una axiología moral edificada sistemáticamente por la circunstancia social [...] el hallazgo principal de los nuevos poetas (Debravo, Aguilar, Albán) consistió en señalar la condición política de la realidad, y en reconocer una función específica del ejercicio literario: testimoniar la historia, sin otra mediación que la vehemencia y un conjunto básico de principios humanísticos [...] Con su actividad se inició un movimiento de ruptura (de naturaleza más que estética, ideológica)" (Monge, 1992: 29-30).

No obstante, rescata Monge (1984: 24): "la recusación abierta de la novedad (estilística, temática o formal)" de Albán, frente a una retórica normativa y tradicional. Rojas y Ovares puntualizan, respecto de los textos albanianos, una búsqueda de lo americano, una "concepción del quehacer poético como instrumento político" (1995: 212), así como una reflexión sobre la escritura poética como representación de la realidad y un interés por reelaborar símbolos, 
mitos y códigos literarios de diferentes tradiciones. Barahona (2011) valora la actitud inconformista, polémica y renovadora de la poesía albaniana, debido a la vigorosa voluntad creativa y crítica, virtudes que le permiten a Albán un constante proceso de superación.

Barahona (2011) identifica a Albán como el participante más activo del grupo Nueva Generación (el autor no menciona a sus integrantes): un grupo de nuevos poetas costarricenses que siente la necesidad de una renovación de la poesía sobre la base de la autenticidad, disciplina, estudio y comprensión del ser del hombre y de las cosas.

Por último, Camacho (1987) sitúa a Albán en el grupo del Manifiesto trascendentalista (el autor no menciona a sus integrantes), el cual se caracteriza por un uso metafórico subjetivo y enigmático, un compromiso histórico y una apertura hacia la comunicación poética. Este crítico afirma que el valor trascendental de la poética albaniana radica tanto "en una visión esencializante de la realidad como en la necesidad de trascender el cuerpo lingüístico del poema" (1987: 373), por medio de la imagen poética.

\section{Facetas de un discurso: La poética albaniana en el marco de la poesía costarricense}

La poesía de Albán ha sido catalogada como práctica de ruptura de acuerdo con la poesía nacional desde la década de los sesenta hasta la actualidad. Su poesía ha sido la de un:

\begin{abstract}
poeta controcorrente, di inesauribile trascendentale che da cinquant'anni colma le sue pagine di transparenza, di immagini ineffabili sorte dagli elementi terrestre, in un'epoca in cui la poesia ha cercato di spogliarsi di figurazioni e avvicinarsi al linguaggio quotidiano, quasi disgregandosi in esso. È raro trovare un autore contemporáneo di questo genere $^{5}$ (Pieragnolo, 2011: 5).
\end{abstract}

Sus textos son partícipes de un esfuerzo por comunicar las realidades ${ }^{6}$ en tanto afirmación, a medida que buscan "desvirtuar y contravenir el concepto de lo poético que en el país se ha empleado de ordinario [...] Su tenacidad de la ruptura se manifiesta entre dos polos: la poesía ponderada y la poesía disidente" (Monge, 1981: 1), pues evita "la timidez metafísica de una gran parte de nuestra tradición literaria y buscó darle a nuestros poemas un patrón retórico más próximo a la rebelión" (Monge, 1984: 120).

Respecto de Albán, González (1986, citado en Chase 1986: XIII-XIV) afirma: “[su] afán de renovación y de superación del pasado de la lírica costarricense" evidencia que "la poesía costarricense salta las fronteras patrias y sienta sus reales en el amplio ámbito de la poesía en lengua castellana”. Durán (2003) concuerda con González al exponer la trascendencia pueblerina y nacional de la poesía albaniana, y reafirma, por otra parte, la superación de su veta inicial respecto de la poesía como instrumento transformadora social hacia una conciencia continental humanista y existencial. Debido a esto: "La obra de Laureano Albán viene así a conformar también la madurez de la poesía costarricense y responde de varias maneras a la modernidad alcanzada por el país en sus manifestaciones culturales" (Durán, 2003: 167), "gracias a su conocimiento de casi todas las vertientes de la poesía y a su ir despojándose de simpatías y afinidades" (Baeza, 1978: 310), pues, como expone von Mayer: "Hombre de su época, Albán no es un precursor, sino síntesis admirable de una tradición literaria vigorosamente conformada" (1995: 563).

De acuerdo con Monge, Albán, Debravo y Aguilar, en el Grupo de Turrialba, consideraron sus prácticas poéticas como "la verdadera nueva poesía de Costa Rica” (1984: 117). Ya desde 1959 marcaban una pauta trascendental tanto local $^{7}$ como nacional (Chávez 1984), desde la cual se fundó posteriormente el Círculo de Poetas Costarricenses (Duverrán 1973, Baeza 1978, Monge 1981, Bonilla 1981, Chávez 1984, Monge 1984, Camacho 1987, Monge 1992, Rojas y Ovares 1995, Quesada 2000, Salas 2000, Durán 2003, Corrales 2007, Soto 2009). Dicha 
visión del quehacer poético influyó en las nuevas generaciones poéticas (Corrales 2007, Soto 2009), inclusive turrialbeñas a partir de 1970 (Chávez 1985), con la publicación del Manifiesto trascendentalista, ante el cual Albán aparece como líder capital (Boccanera 2004, Corrales 2007).

No obstante, cada uno de estos poetas manifestó rumbos distintos. Se han tratado de establecer similitudes entre las poéticas albaniana y debraviana (Corrales 2007), así como diferencias (Baeza 1978). González respalda la divergencia entre ambos poetas, pero sin desligarlas del todo, dado que Albán: "En cierto sentido busca una senda opuesta a la de Jorge Debravo; pero con la misma intención: imponer un nuevo modo de hacer poesía en Costa Rica" (1986, citado en Chase 1986: XIII). Por tanto, a pesar de sus diferencias estéticas, su perspectiva inicial de grupo se concretó, de modos distintos, en los proyectos ideológicos de ambos: disentir de la tradición lírica nacional y posibilitar una resignificación de esta.

El lenguaje poético, estética e ideología albanianos han sido objetos de estudio. La riqueza estética en la producción albaniana, desde sus inicios, se ha caracterizado por un contacto con otras culturas y nociones sobre el hecho poético, desde donde se logra "un cosmos poético más complejo y variado" (Monge 1984: 68). Las premisas evolutivas de sus textos radican en "la pasión por convertir en metáfora y símbolo el conocimiento de la realidad" (Monge 1984: 182, 1987: 315) y en "promover en el lector una nueva idea del poema, que mucho pudiera tener de conocimiento intuitivo mágico y poco de la actividad racional en el proceso recreador de la lectura" (Monge 1987: 318). Del mismo modo, se diferencian los esfuerzos albanianos por perfeccionar los sistemas expresivos, el valor universal y orígenes de los temas abordados (Monge 1984).

González (1986, citado en Chase 1986: XIII-XIV) observa, en los poemas de Albán, "una estructura poética cuyo componente semántico es tan intenso que perturba y casi obstaculiza los aspectos formales del poema, hasta un equilibrio magistral en donde el material sonoro y las distintas dimensiones significativas del poema se funden".

Por su parte, Azofeifa (s.f., citado por Duverrán 1973) recalca el tono litúrgico y optimista en el tratamiento de los temas albanianos. Baeza se refiere a dicha poesía como un "descubrimiento del ser a través de una galaxia de imágenes, símiles y símbolos líricos" (1978: 316), logrados a partir de una cotidianidad trascendentalista, "la imaginación sensitiva, la sensibilidad pensante" (1978: 307). Camacho defiende que este poeta consigue el ideal de la imagen visionaria de acuerdo con los principios del Manifiesto trascendentalista, de manera cabal y diferencia de los otros firmantes de este texto, pues: "En Albán, las imágenes apelan más a lo afectivo que a lo intelectual; a ello deben su carácter difuso, a veces, inclusive, mágico" (1987: 374).

En sí, se precisa una poética albaniana vista, en sus más amplios sentidos, como una exploración de lo común y cotidiano, a partir de la palabra poética y una realidad cósmica, en tanto culto al lenguaje e imagen poéticos, y una conciencia del desencanto (Monge 1984). Para Albán, la claridad de expresión debe permitir los niveles de sugerencia, la belleza de una estructura lírica en donde se consustancien forma y fondo (Barahona 2011). Estos esfuerzos solo se consiguen a través del ejercicio del genio creador, el cual, según Albán, permitirá la creación de una obra máxima y universal (Barahona, 2011).

Al respecto sintetizan Fornoff y McClintock:

Hace más de treinta años que Albán escribe contra la corriente, un fiel e infatigable trascendentalista, cuya visión necesita para ser comunicada de dúctiles imágenes que abarquen lo inefable, pero quien escribe en una época donde la poesía se ha esforzado por adelgazarse, para despojarse de imágenes y acercarse a lo numinoso en el lenguaje prosaico, o deshacerse en ello (1995: 19-20). 


\section{Etapas de la poética albaniana}

Obsérvese, primeramente, en el siguiente cuadro, la producción total ${ }^{8}$ de Albán hasta la fecha:
Monge (1984) y Amoros (1987) han dividido la producción poética albaniana en etapas con el fin de facilitar sus análisis temáticos y formales.

\section{CUADRO 1}

Bibliografía de Laureano Albán

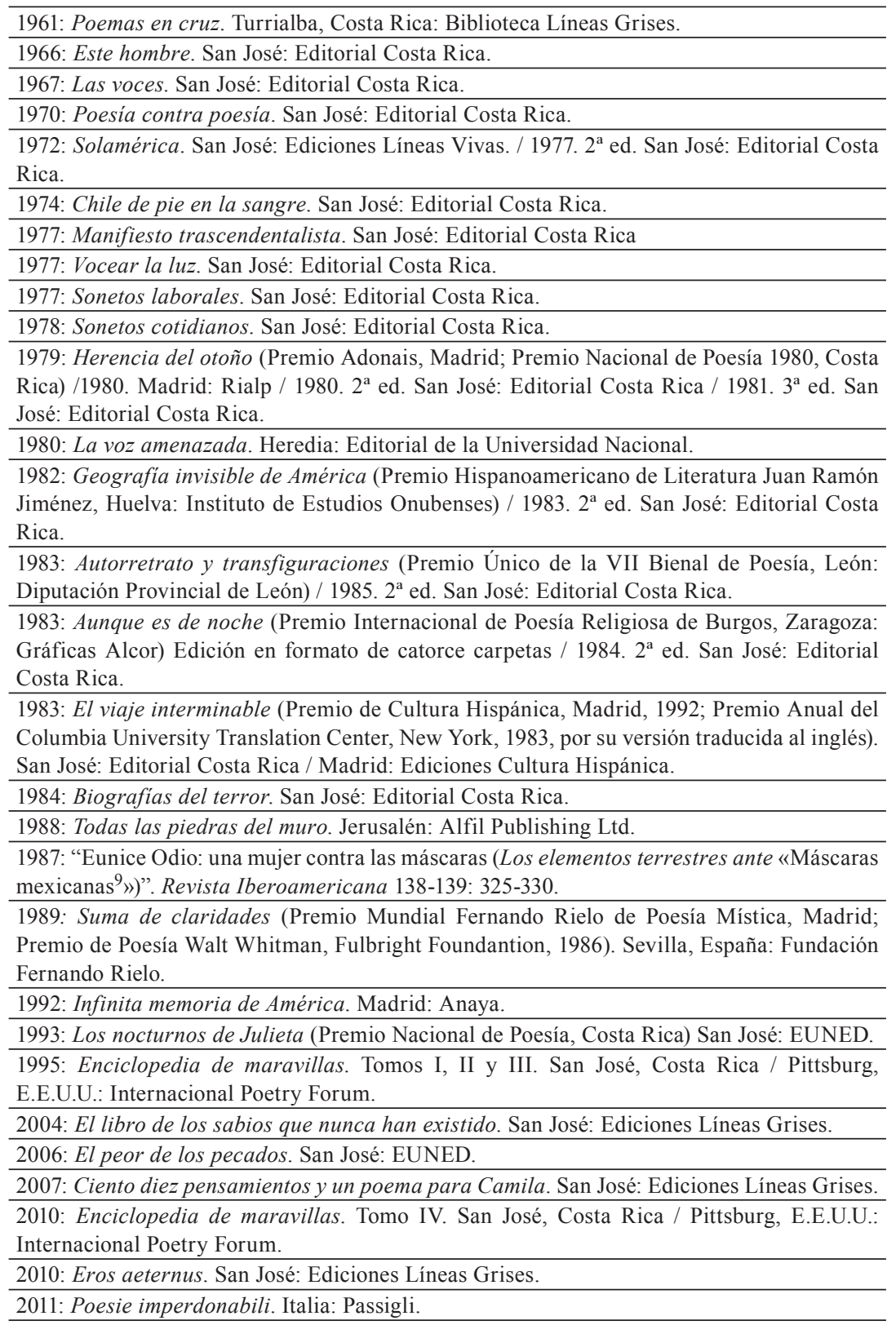


Por su parte, Monge (1984) dictamina un corpus relativo a una faceta inicial sociopolítica, el cual incluye: Este hombre (1966), Las voces (1967), La voz amenazada (1980), Sonetos laborales (1977), Sonetos cotidianos (1978), Chile de pie en la sangre (1974) y Biografías del terror (1984). Ubica a Las voces y Solamérica (1972), como textos de un período de transición a partir de una referencia de la realidad concreta, la cual termina convirtiéndose en un problema retórico. Chile de pie en la sangre conformaría una etapa de ruptura sustentada en el culto al lenguaje y a la imagen poética. No obstante, Herencia del otoño (1979) es referido como punto decisivo de la madurez poética de Albán.

A su vez, Amoros (1987) señala tres períodos en la poesía albaniana:

a) Inicial: Desde 1961, con la publicación de Este hombre, hasta 1978. Se incluyen los poemarios: Las voces, Solamérica, Chile de pie en la sangre, Vocear la luz (1977), Sonetos laborales, Sonetos cotidianos; así como los ensayos Poesía contra poesía (1970) y Manifiesto trascendentalista (1977). No se presentan criterios de homologación formal ni temática respecto de los poemarios. Sin embargo, se anuncia el predominio de una poesía existencial, cotidiana e íntima; una inquietud religiosa, en Este hombre, particularmente; un modo narrativo, el cual evolucionaría en el tono épico de Geografía invisible de América (1982) y El viaje interminable (1983); así como la recuperación del pasado en tanto sustento de la actual realidad latinoamericana, primero, en Las voces y, posteriormente, en estos dos últimos poemarios.

b) Transición: Herencia del otoño y La voz amenazada son evaluados como fronteras entre dos etapas, debido a la recurrencia y contacto con la tradición poética y vivencia cultural españolas; así como un avance en los rasgos formales de precisión, concisión, síntesis y léxico. c) Madurez: Es marcada por Geografía invisible de América, El viaje interminable y Biografias del terror, pues conjugan un dominio de las mitologías telúricas y culturales de América, y a la voz testimonial y denunciante de las crisis sociopolíticas del continente, trascendiendo la crónica y el dato concreto. Esta corresponde a una etapa aún abierta. Los textos Aunque es de noche (1983) y Autorretrato y transfiguraciones (1983) serían situados de igual manera en este período, pues comprenden una síntesis de las tradiciones estéticas española y latinoamericana.

De acuerdo con la fecha de publicación de cada uno de los poemarios, la organización de Amoros (1987) evidencia un ordenamiento cronológico acorde con el grado de madurez literario de Albán, puesto que Monge (1984) sugiere, por ejemplo, que textos como Biografías del terror se encuentren en una etapa inicial, cuando es, en su criterio, Herencia del otoño el texto que marca la etapa de mayor madurez; y textos como Las voces y Solamérica marquen un período de transición, frente a Chile de pie en la sangre, Vocear la luz, Sonetos laborales y Sonetos cotidianos; todos previos a Herencia del otoño. El ordenamiento de Monge (1984) sugiere un retroceso, estancamiento y avance arbitrarios en la producción poética de Albán, en comparación con la linealidad evolutiva observable en la categorización de Amoros (1987).

En la cronología y división de Amoros (1987), se observa la trayectoria por que ha atravesado la producción poética albaniana, "desde su juventud pueblerina y aislada hacia la actualidad cosmopolita; desde un ayer algo limitado hasta alcanzar plenamente el presente para situarse en el espacio mayor de la poesía hispanoamericana contemporánea" (Durán, 1995: 1083).

Para una mayor visualización integrada de la tensión a la hora de establecer los límites de las etapas de la producción albaniana según Monge (1984) y Amoros (1987), obsérvese el siguiente cuadro. 
CUADRO 2

Etapas de la producción poética albaniana

\begin{tabular}{|c|c|c|}
\hline Monge (1984) & Etapa & Amoros (1987) \\
\hline \multirow{2}{*}{ Este hombre } & \multirow{9}{*}{ Inicial } & Este hombre \\
\hline & & Las voces \\
\hline Las voces & & Poesía contra poesía \\
\hline Chile de pie en la sangre & & Solamérica \\
\hline Sonetos laborales & & Chile de pie en la sangre \\
\hline Sonetos cotidianos & & Manifiesto trascendentalista \\
\hline La voz amenazada & & Vocear la luz \\
\hline \multirow{2}{*}{ Biografias del terror } & & Sonetos laborales \\
\hline & & Sonetos cotidianos \\
\hline Las voces & \multirow{2}{*}{ Trancisión } & Herencia del otoño \\
\hline Solamérica & & La voz amenazada \\
\hline \multirow{5}{*}{ Herencia del otoño } & \multirow{5}{*}{ Madurez } & Geografía invisible de América \\
\hline & & Autorretrato y transfiguraciones \\
\hline & & Aunque es de noche \\
\hline & & El viaje interminable \\
\hline & & Biografías del terror \\
\hline
\end{tabular}

\section{Principales críticas y valoraciones sobre los textos albanianos}

Las críticas y valoraciones presentadas a continuación se cimientan en diecinueve textos albanianos. Se seguirá, por tanto, el orden cronológico de la producción de este poeta, en la medida de lo posible, pues algunos críticos establecen comparaciones o contrastes entre los textos.

En primera instancia, Monge (1984) cita solo una vez a Poemas en cruz (1961) durante su estudio y declara un desconocimiento del público lector ante este texto. Inicialmente, Poemas en cruz, junto con Este hombre, aborda la existencia humana y una reflexión sobre el mundo, desde un uso expresivo y un verbalismo moral apartados de la retórica tradicional costarricense.

Este hombre marca un límite de promoción poética, en 1967, junto a Canciones cotidianas, de Debravo; y Los reinos de mi mundo y Árbol del tiempo, de Chase (Monge 1984). Se detecta ya en este texto una premisa fundamental durante la producción primera de Albán: "cierta índole del humanismo que quería ponerse incluso al margen de la contingencia y la inmediatez" (Monge, 1984: 127); esto es, una fe vital e impetuosa en el ser humano, en medio de una realidad caótica, no absurda, marcada por las temáticas de la muerte y la desolación.

Monge (1984) establece comparaciones entre este y otros textos albanianos. Por ejemplo, homologa Este hombre con Sonetos cotidianos, considerando el tratamiento del arquetipo del poeta como abandonado en el mundo. Asimismo, lo compara con $L a$ voz amenazada y Chile de pie en la sangre, en tanto se sustentan sobre una realidad particularmente estetizada desde la angustia, la esperanza, la nostalgia y una sensación de desamparo existencial. Junto a este último texto y Las voces, Este hombre "busca la conciliación entre la condición perecedera y material del ser humano y el mundo absoluto de Dios" (Monge, 1984: 83); lo mismo es analizado 
por Amoros (1987), en lo que respecta a una inquietante preocupación religiosa.

Baeza (1978) discute el papel crítico de Albán en su texto Poesía contra poesía, donde este último exige la revisión de aspectos como: la tradición poética y la mediocridad imperante en la poesía de Costa Rica, la falta de verdadera crítica literaria en el ámbito nacional, la centralización del poder editorial, la búsqueda y estímulo frente a los instrumentos estilísticos de la poesía y la perspectiva del trascendentalismo. Frente a la mediocridad y la pequeñez de la poesía costarricense, Albán analiza las fallas de los poetas anteriores a 1960, con el fin de sugerirles rumbos significativos a las nuevas generaciones de poetas (Barahona 2011). Monge (1984) establece que este texto casi no ha sido analizado y, además de las ideas expuestas por Baeza (1978), aborda la problemática del poeta, su reconocimiento en medio de un sistema editorial y mercantil que privilegia los valores de la narrativa.

Solamérica es considerado ejemplo de una poesía visionaria que ataca el conceptualismo (Monge 1981), con base en una "ambición técnica, temática y de contenido lírico" (Baeza, 1978: 307), las cuales ofrecen una nueva visión sobre aquello conocido como 'poema', en tanto "conocimiento intuitivo y mágico y poco de la actividad racional en el proceso recreador de la lectura" (Monge, 1987: 318). Se advierten en él relaciones intertextuales ${ }^{11}$ con otras producciones poéticas contemporáneas a la década de los setenta, debido a sus dimensiones estéticas y morales; verbigracia: Canto general, de Neruda, según "propone una visión distinta de su referente: América no sólo es una geografía y una historia (a la manera del [texto nerudiano]), es sobre todo una vivencia y una sublimación de un concepto histórico" (Monge, 1984: 73).

Este texto le permitió a Albán una autocrítica sobre los riesgos del lenguaje hermético, así como las desmesuras y el radicalismo de la retórica de la sublevación del lenguaje. Al respecto, dice Albán:

esta desesperada carrera por los túneles luminosos de la imagen poética fue también la huida compulsiva, el vehemente acto de romper el cascarón mimético y limitante de la mediocridad históricamente caracterizada por la imagen poética descolorida, plana, sin vigor y sin originalidad. Todas ellas, constantes históricas en nuestra literatura que he intentado superar en las imágenes de «Solamérica» (1977, citado en Monge 1984: 180).

Monge (1992) compara Solamérica con Geografía invisible de América y Chile de pie en la sangre, pues estos textos aun remiten a un modelo ideológico primigenio del ser humano, ya sea frente al ámbito maquinizante de la ciudad, ya frente al tópico histórico del espacio americano como "vergel" natural y originario, desde una perspectiva utópica, paradójica e histórica, reformadora del mundo entre "la imagen y un complejo sistema simbólico, la seguridad ontológica; la búsqueda del origen de lo americano" (Monge, 1984: 68).

Por otra parte, Monge asemeja Chile de pie en la sangre con La voz amenazada debido a su retórica, pues ambos buscan quebrantar la lírica conceptual presente en la práctica poética costarricense, primero, por un perfeccionamiento expresivo y, luego, por el deseo de "rehuir el peligro de la incomunicabilidad y la síntesis a ultranza" (1984: 172, 1987: 309). Junto a Chile de pie en la sangre, Solamérica configura una poética de la historia y un preámbulo para otras prácticas poéticas, como la de Julieta Dobles (Monge, 1984).

Chile de pie en la sangre, en sí, corresponde a una "alianza de un fuerte compromiso políticosocial con una calidad lírica indudable" (Baeza, 1978: 307). Al igual que Biografías del terror, conforma una poesía social y testimonial, una "configuración política [...donde...] La patria, el pueblo, el compatriota, el soldado, la amada, los hijos, los hermanos son los destinatarios que comparten con el sujeto poético una específica y local circunstancia [...es decir...] la ética del amor por los humillados y las víctimas del poder político" (Monge, 1992: 30).

Según Pieragnolo, Chile de pie en la sangre aparece "dopo la profonda crisi personale documentata nel libro del 1981 La voz amenazada, in cui il poeta prese coscienza del fallimento dell'illusione giovanile, comune del resto a molti scrittori della sua generazione, de fare della poesía lo strumento transformatore della società e del sentiré umano, il 
disinganno e la frustrazione conseguente trovarono in qualche modo una salvezza ontologica nella parola e nella coscienza della perdita ${ }^{12} "$ (2011: 7).

El Manifiesto trascendentalista, "el primer y único manifiesto literario que se ha hecho en Costa Rica" (Dobles 2008, citado en Rodríguez 2008: §11), corresponde a un análisis reflexivo sobre la creación poética y literaria en general, no analizado en sí hasta el momento, sino más bien abarcado a partir de citas y referencias en los distintos estudios consultados sobre la historiografía costarricense. Sin embargo, Rodríguez se refiere a este texto como:

El mayor esfuerzo de sistematización teórica de esta formación discursiva" (2006: 112) trascendentalista en la poesía costarricense; especifica que, a pesar de ser este un texto programático, "no presenta mayor novedad, en sus fundamentos, sobre los planteamientos que sobre poesía ya se habían realizado desde Platón hasta Dámaso Alonso y la estilística de los años 50 (2006: 112).

Boccanera (2004) habla del Manifiesto trascendentalista como un texto ensayístico de tono parricida y sarcástico, más que programático, el cual conserva contradictoriamente una línea tradicional y anclado de lo esencial poético, tanto en la literatura de Costa Rica como universal, debido a las citas de Darío, Apollinaire, Pound, Brenes Mesén, Huidobro, Basileo Acuña, Amighetti, Machado, entre otros, en sus capítulos $^{13}$. Corrales (2007), arbitrariamente, remarca que dicho texto fue escrito por Albán por la búsqueda de reconocimiento y poder simbólico ${ }^{14}$; propósito firmado luego por Dobles, Bonilla y Monge ${ }^{15}$.

Boccanera (2004) y Monge (1999) rescatan que las proposiciones del Manifiesto trascendentalista definen una poesía en contra de las producciones circunstanciales de una época, en medio de un contexto de crisis moral, política y literaria en Centroamérica y América Latina, en general: "Vale decir que dicho Manifiesto irrumpe en un clima de polémicas culturales y de recrudecimiento en las luchas políticas centroamericanas" (Boccanera 2004: 114). Si bien el Manifiesto trascendentalista corresponde a una síntesis de la formación discursiva trascendentalista, remota a los textos poéticos de la Lira costarricense (1890) en el eje diacrónico de la poesía nacional, constituye para Rodríguez, por tanto, "una reacción y cura en salud contra la poética conversacional que estaba escribiéndose en Centroamérica durante las décadas del 60 y el 70 [...desde...] una concepción ahistórica del fenómeno poético de claras resonancias platónicas" (2006: 112).

Monge (1999) valora la posición del trascendentalismo, expuesta por el Manifiesto trascendentalista, como una estética que supere los signos históricos, el fanatismo de las ideologías, el rechazo por la cultura de masas; así como las sociedades de consumo (Corrales 2007). De igual manera, afirma Monge (1999) que el recibimiento y aceptación del Manifiesto trascendentalista se han caracterizado por un alto grado de resistencia y contrarrespuestas de poetas de los años setenta, ochenta y noventa, como los manifiestos publicados por la revista Oruga, la editorial Alambique y Mauricio Molina (Boccanera 2004), a pesar de que Corrales insiste en decir que: "Dicho documento, de escasa repercusión, fanfarronea y aboga por una poesía metafórica y de lenguaje figurado, donde la intuición sería el centro de la creación poética ${ }^{16 "}$ (2007: 29). En todo caso, a tal punto ha llegado la presencia e importancia del Manifiesto trascendentalista en los grupos y las producciones literarios costarricenses, que un grupo de autores se ha visto en la necesidad de autodefinirse como antitrascendentalistas (antilirismo costarricense), al contraponerse, entre otras razones: "1. A la expresión de los poetas del trascendentalismo, mediante el empleo de un lenguaje coloquial y casi libre de connotaciones metafóricas" y "2. A los herederos del trascendentalismo, muchos de estos reunidos en talleres literarios" (Fernández 2012: §11).

En todo caso, Rodríguez asegura que el discurso trascendentalista redactado y manifiesto por Albán en sus textos constituye un paradigma poético en la diacronía literaria costarricense, pues "sigue siendo un importante referente para la práctica de la escritura lírica, gracias a su asentamiento enunciativo, su legitimación referencial y sus modelos de producción históricos" (2006: 116). 
En relación con Sonetos laborales, y Sonetos cotidianos posteriormente, Monge (1981) exalta una madurez estética de la imagen albaniana, a partir de "la persistencia de una figura estrófica tradicional [el soneto clásico] junto a un esfuerzo retórico novedoso" (1987: 314). En esta nueva etapa, se señala una afirmación poética "no desde una tónica metafísica y generalizante, sino desde las cosas cotidianas y simples, con lo que se reinstala en cierto modo con la nostalgia de lo elemental y primigenio, y se separa del radicalismo retórico experimentado en Solamérica" (Monge 1984: 58); es decir, una "presencia de lo humano en los objetos diarios, aún en aquellos elementos que por su misma naturaleza poco tienen en común con nuestra condición" (Monge 1984: 69).

Una lectura intertextual evidente entre este proyecto poético albaniano (Sonetos laborales y Sonetos cotidianos) y las Odas elementales, de Neruda, es sostenida por Monge (1984), debido a los mismos propósitos estéticos e ideológicos al asumir la cotidianidad.

Monge (1984) rescata, además, que en los "Sonetos conyugales", apartado de los Sonetos cotidianos, se manifiesta un erotismo desde una ambientalidad cotidiana y doméstica; en otras palabras, una poesía amorosa obediente a una negación de la realidad conflictiva, con tal de sostener una afirmación existencial en el optimismo: el tópico del amor como causa y efecto de la armonía universal.

Herencia del otoño viene a conformar un fundamento estético distinto de los textos albanianos precedentes, pues "busca explorar (o reexplorar) las posibilidades de la extensa tradición de la poesía española. El movimiento al que se aboca Herencia del otoño corresponde a la alianza de la poesía hispánica de dos continentes literarios: el peninsular y el americano" (Monge 1981: 5). Pieragnolo (2011), Durán (1995), y Fornoff y McClintock (1995) comparten esta última afirmación. Rodríguez caracteriza este texto, a partir de uno de sus poemas ("Tránsito del hombre"), como "un universo de claras resonancias auráticas" (2006: 113). Fornoff y McClintock (1987) se refieren a él como una autodefinición y renovación dentro de la producción poética de Albán, por su visión afectiva y simbólica del ejercicio poético; Rosales, como una "poesía esencializada y reflexiva, desnuda pero sencilla" (1980: 5B); Baeza (1980), cual un texto de mirada multidireccional y fuerza expresiva. En fin, una "poesía deslumbrante" dice Doucet (2009: 8).

En relación con la temática de Herencia del otoño, Monge (1981) propone al menos cuatro tópicos fundamentales: 1) La alianza existencial entre la naturaleza y el ser; 2) el ser humano como la proyección del ser en las cosas circundantes; 3) la visión del ser humano en medio de la realidad natural; y 4) el tiempo como creador y destructor de realidades. Monge (1984: 69) sintetiza dichos tópicos en "la reafirmación del ser, a partir de una evocación del mundo natural (su símbolo: el otoño), y por otro [...] la permanencia material del ser humano". Rosales (1980) formula, como bases textuales, los temas de la amistad, el dolor, la naturaleza y la herencia española. En todo caso, se circunscriben ambas perspectivas en una incertidumbre respecto de la realidad inmediata y evidente del mundo.

Chaves (1987) expone la primera tesis de licenciatura realizada en Costa Rica sobre la producción poética de Laureano Albán: $L a$ interoceptividad: Paradigma fundamental en el universo semántico de Herencia del otoño. $\mathrm{Su}$ lectura evidencia un análisis, desde la semántica estructural, propuesta por Greimas (1976), sobre la estructura paradigmática y la confirmación de la homogeneidad del texto en torno a una isotopía existencial del yo lírico, a partir de oposiciones binarias: estado eufórico (la vida) opuesto a un estado disfórico (la muerte). Chaves concluye, al respecto: "la organización de una base clasemática marcada por la /+Interoceptividad/ [...] define el discurso estudiado, como un discurso mítico, propio de la dimensión noológica" (1987: 216-217).

Chaves (1987), en su estado de la cuestión, subraya la atención de los críticos sobre este volumen a partir del premio Adonáis obtenido en España en 1979. Por ejemplo: Azofeifa (1980) y Tovar (1980) rescatan la vivencia del otoño como motivo columnar del texto; Jara (1980), la referencialidad del ámbito natal del poeta 
tanto americano como español, en medio de un intento por conjugar ambas herencias hispánicas, una limpieza y fluidez del lenguaje mayores en relación con sus textos precedentes. Fajardo (1982) plantea una lectura biográfica en el poemario. Cabrera (s.f., citado en Chaves 1987) sintetiza el contenido poético de Herencia del otoño en dos núcleos: la soledad y el dolor. Castro (s.f., citado en Chaves 1987) y Cortés (s.f., citado en Chaves 1987) se delimitan a la observación de aspectos formales del texto, como los recursos retóricos y léxicos. En última instancia: "Se considera el discurso de Herencia del otoño como polivalente, en cuanto a la determinación del objeto poético" (Chaves, 1987: 12).

Sobre La voz amenazada, Monge enfatiza una doble y simultánea vertiente poética en el texto: "una conciencia de la frustración y una salvación ontológica" (1984: 173, 1987: 309). Por su parte, Baeza (1978) iguala La voz amenazada a Biografias del terror, pues ambos recrean el compromiso político denunciando el desenlace trágico de múltiples víctimas de las dictaduras militares de América del Sur. Según Pieragnolo, Albán, en Chile de pie en la sangre, La voz amenazada y Biografías del terror: "Concentrò l'attenzione sul resto del suo continente scosso da regimi autoritari, cercando di rispondere ad una necessità personale e generazionale. Prese parte al dramma che divise il continente e dedicò la sua opera alle vittime delle dittature militari, che padroneggiarono nel Sud America fino alla metà degli anni Settanta ${ }^{17 "}$ (2011: 7-8).

Geografía invisible de América constituye la exaltación poética de Albán sobre "Tres pueblos, tres referentes culturales, tres geografías de lo inmenso aunque invisible para configurar un canto en el que están presentes el pasado, el presente y se adivina el futuro" (Doucet, 2012: 3). Amoros se refiere a este poemario cual: "Una búsqueda que elige la palabra como vía de conocimiento, y si — como ha dicho Guillermo Carnero- la gran aventura de la poesía del siglo XX es la lucha dialéctica entre el lenguaje mítico y el lenguaje lógico, no cabe duda de que esta poesía se sitúa de lleno en la encrucijada de su época" (1987: 353). La autora exalta el "estudio de los códices, mitos y leyendas nahuas y mayas, para tratar de revivir en un lenguaje poético contemporáneo la profunda e inquietante cosmovisión de las culturas precolombinas [...] una posible perspectiva de la América trascendental, invisible, más allá de su historia y de su geografía física" (Albán 1982, citado en Amoros 1987). Fornoff y McClintock llaman a esta última empresa una "construcción mitopoética de la realidad hispanoamericana con su evocación de los dos espacios culturales del hispanismo, frecuentemente ignorados" (1995: 25), igualmente presentes en El viaje interminable, "[para muchos] su logro poético más importante, ya que constituía un género radicalmente nuevo: la fusión de lo lírico y de lo épico" (Fornoff y McClintock 1995: 23). Ambos textos, así, configuran cantos testimoniales históricos (historicidades concretas), donde la palabra funge como crónica del tiempo americano (Rodríguez 2006), un aspecto también evidente en Infinita memoria de América (Monge 1998).

Doucet, respecto de Geografía invisible de América, expresa que "el poeta es la voz actualizada de las mal llamadas culturas «débiles»" (2012: 1). Esta investigadora se concentra en el tercer libro de este poemario, el cual está dedicado "al pueblo quechua testimoniando su presencia en el cosmos y manifestando su relación de identidad con su geografía originaria" (Doucet, 2012: 2).

Plantea un análisis de dicho libro a partir de la teoría de los polisistemas de Even-Zohar. Con dicho marco teórico, observa una sincronía de tres momentos que conforman un sistema múltiple de intersecciones y superposiciones mutuas de elementos interdependientes entre sí, tales como: a) "el momento sincrónico en el que el poeta Laureano Albán escribe los poemas partiendo del legado ${ }^{18}$ que autores históricos y de cuyos escritos recupera fragmentos a modo de citas para encabezar sus poemas: Inca Garcilaso, Padres agustinos, Huamán Poma de Ayala, etc.”; b) "el tiempo pretérito en el que dichas obras se escribieron para recoger unas tradiciones o unas voces con amenaza de perderse a causa de la colonización hispánica de la geografía americana: a partir del siglo XVI"; c) "un pasado remoto dónde esas voces u esas tradiciones 
eran algo vivo, visible y fácilmente identificable entre el pueblo quechua y sus predecesores: jaillis, plegarias, himnos" (Doucet, 2012: 4). Tales elementos configuran "un universo poético pleno en identidades y referentes culturales que al influenciar diacrónicamente sobre otros textos configurarán una multiculturalidad de la que el poeta extrae y hace visibles esas identidades" (Doucet, 2012: 4).

En síntesis, en Geografía invisible de América, la palabra poética de Albán "se convierte en algo más, en un instrumento para la reflexión sobre la responsabilidad humana en la conservación de las identidades" (Doucet, 2012: 9). Es, en términos también de Doucet, una poesía "de indagación en las raíces hispanoamericanas y en el ansia española de nuevos horizontes" (2009: 8). Sintetiza Pieragnolo:

El viaje interminable descrisse il viaggio della scoperta del nuovo mondo e la conseguente distruzione/creazione del continente con un lirismo epico, mentre nel successivo Geografía invisible de América cercò di restituiré l'essenza spirituale della sua ascendenza con l'invocazione elegiaca del paesaggio delle tre grandi civiltà precolombiane (Azteca, Maya, Inca) per giungere alla costruzione mito-poetica della realtà ispanoamericana, coinvolgendo entrambe le culture dell'ispanismo ${ }^{19}$ (2011: 7)

En Autorretrato y transfiguraciones se abarcan las preocupaciones por la existencia, el tiempo, el engaño y limitación de los sentidos, de acuerdo con Rojas y Ovares (1995); una configuración del cosmos (Durán 1995); un espacio poético en donde se presenta "la visión trascendental con más intensidad [...por medio de...] la tensión radical interior entre la presencia y ausencia [...] de imágenes de fuerza destructiva, aun apocalíptica" (Fornoff y McClintock, 1987: 334). Pieragnolo afirma que se trata de un "viaggio attraverso il proprio paese, le voci, le risposte, i mormorii, gli stimoli di una nouva e reciproca riscoperta, continuando nell'esaltazione delle immagini e delle metafore, in una continua fusione e conversione degli elementi naturali per la costruzione di un diverso cosmo dove riconoscersi ${ }^{20}$ " (2011: 8).
Rojas y Ovares (1995) afirman que las temáticas erótico-religiosas son recurrentes en Aunque es de noche, texto caracterizado por símbolos de la poesía mística de San Juan de la Cruz; "un homenaje y una evocación de San Juan de la Cruz" (Mora, 1985: 82); un intento que Cros (1984) denominó como: "una aspiración a la comunión con Cristo" (1985, citado en Albán 1986: 27). Mora (1985) analiza un tono existencial sobre las temáticas de la soledad, la muerte, el tiempo y la angustia, a partir de la contemplación subjetiva albaniana de la naturaleza, donde la noche es símbolo de tránsito metafísico, junto al cual la figura de Dios no aparece como salvador o necesidad existencial, sino como un guía meramente metafísico del ser humano, pues Él es ausencia y garantiza metafísicamente el accionar humano, la consistencia ontológica a los objetos materiales y el quehacer del poeta; Él configura todo alrededor de la voz lírica y se refleja indirectamente en la otredad humana o de la naturaleza. Dice Durán: "el canto se mantiene fiel en dirigir sus dudas al Señor, en esperar de Él las respuestas a las vacilaciones del escritor y a las de su pueblo, como si el poeta encarnara también una personalidad colectiva, por sobre su papel individual" (2005: 1093).

Por su parte, Pieragnolo afirma sobre Aunque es de noche:

\footnotetext{
Tredici canti che riassumono una denuncia colma di modernità, l'ansia contemporanea di tutti gli uomini e l'antica domanda, che attende la luce nel mezzo delle ombre universali; benché in questi versi non ci sia cieco ottimismo, nemmeno c'è totale disperazione, perché la notte resta simbolo di una continua ricerca del dialogo e del confronto con $\operatorname{Dio}^{21}(2011: 8)$.
}

Desde este punto de vista, Mora (1985) establece diferencias claras entre la poética mística de San Juan y Albán; puesto que, en aquella, Dios es Plenitud, Amor; representa el objeto de éxtasis, encuentro con el Amado y permite que los textos sean un medio didáctico de esta experiencia (Itinerarium mentis in Deum); mientras que en la poesía mística de Albán describe la influencia de la filosofía de San Agustín y el existencialismo de Kierkegaard, 
pues Dios aparece más como un recurso literario, que como un verdadero diálogo de fe.

Por otra parte, Fornoff y McClintock (1987) también consideran El viaje interminable como "fusión de la lírica y la épica, ella debido a su regreso a los orígenes mesoamericanos e hispánicos y el cataclismo de la conquista" (Durán, 2003: 172). En palabras de Amoros, este texto representa: "el aliento cósmico y visionario que informa la voz de los verdaderos mitos, la aventura del descubrimiento de América, que es el punto axial en que se funden las culturas precolombinas e hispánicas" (1987: 355); es "una historia poética del descubrimiento" (Berroa, 1983: 583).

Biografias del terror resignifica poéticamente "el horror de las dictaduras militaristas padecidas entonces por Argentina, Chile y Uruguay" (Durán 1995: 1090): la historia trágica de al menos cuarenta y cuatro víctimas ${ }^{22}$ de los sistemas opresores y dictatoriales en América del Sur entre 1973 y 1977, a partir de la documentación objetiva brindada por Amnistía Internacional, de modo que busca "dar a sus sacrificios una condición espiritual e ideológica" (Cros 1985, citado en Albán 1986: 12); “busca hacer poesía con la verdad, con la realidad tras la consulta de los informes de Amnistía Internacional, con unos hechos incómodos $\mathrm{y}$ silenciados ante los que se ha mirado demasiadas veces hacia otro lado" (Breto, 2011-2012: 8). A lo largo de este texto de "poesía comprometida" (Doucet, 2009: 8): "el poeta desempeña su papel, un papel eminentemente social y espiritual que no se puede desconectar de la praxis política" (Cros 1985, citado en Albán 1986: 15). Según Fornoff y McClintock, este texto "preserva la función trascendental, dando voz en los poemas sólo a las víctimas, evitando la condena directa ${ }^{23}$ de los agentes de las barbarie del estado" (1987: 334).

Breto, analizando la estructura del poemario, presenta cómo en Biografías del terror "la denuncia política puede convivir con el arte de la literatura" (2011-2012: 4). Ello, según este investigador español, es posible mediante el recuerdo y la evocación de las víctimas de los genocidios latinoamericanos, asumiendo simultáneamente un compromiso político y estético, sin que aquel subestime el segundo. Este proyecto poético de Albán es, en resolución, según Breto, un compromiso humano y literario. De ahí que llame a Albán “«poeta de la Transparencia», dado que sus poemas redimen al condenado, a las víctimas a las que se les ha robado su derecho a la muerte provocándoles esa muerte" (2011-2012: 24).

Cros (1984) insiste en comparar dicho texto albaniano con Canto general de Neruda, no solo por el abordaje transhistórico de su temática, sino porque reconoce un tratamiento divergente respecto de la creación metafórica: "aunque se pueda hablar de tal coincidencia, el universo poético de Laureano Albán es, sin embargo, profundamente original" (1985, citado en Albán 1986: 19-20).

La constancia de la muerte, la agresividad y la fugacidad de la existencia llevan a pensar a Cros (1984) en otras relaciones intertextuales, pero esta vez con Residencia en la Tierra, en tanto se iguala una visión entre la vida y la muerte "como las extremidades alternas de un movimiento cíclico continuo" (1985, citado en Albán 1986: 30), a pesar de que en Albán se enfatiza "el prolongamiento de la vida más allá de la muerte" (Cros 1985, citado en Albán 1986: 30), noción por sí misma manifiesta pocas veces en Neruda según este crítico. Breto (2011-2012) también establece ciertos rasgos parecidos entre este texto albaniano y Residencia en la tierra, principalmente con respecto a la dimensión trágica que permite una poesía de abordaje político-metafísico.

En sí, la perspectiva idealista y espiritualista de Biografías del terror obedece a un sustrato cultural cristiano, el cual coincide "con los criterios materialistas del autor de Canto general para denunciar todos los ataques que afectan aquel santuario de la vida que es el cuerpo del hombre y a los cuales se les considera como otros tantos crímenes contra la humanidad" (Cros 1985, citado en Albán 1986: 31).

Por otra parte, de acuerdo con Durán (2003), Todas las piedras del muro constituye el texto donde logra articular las tradiciones del cristianismo y el judaísmo, orientadas a reflexiones hieráticas y humanas a partir del 
Viejo Testamento; esta es una "poesía que sabe profundizar en otras culturas" (Doucet, 2009: 8). En este poemario, "la fe cristiana [...] tiene que ver más que con un asunto de orden filosófico, con una aspiración a lograr un orden entre lo inmediato y lo que aún no ha sido aprehendido a cabalidad" (Monge, 1984: 87). Se trata de "cien poemas de inspiración bíblica que captan la quintaescencia de la cultura judaica" (Fornoff y McClintock, 1995: 25), "pubblicato in una singolare edizione in quattro lingue (spagnolo, inglese, francese ed ebraico), come omaggio del popolo costaricano a quello israeliano ${ }^{24}$ " (Pieragnolo, 2011: 9). Durán (1995) expone también esta última idea.

Inexplorado, Suma de claridades (1989) aborda la visión nostálgica de la infancia y los paisajes de la niñez. Se trata de un texto, "in cui il poeta recuperò l'intensa influenza e l'emozione dei luoghi della propria infanzia e della famiglia originaria ${ }^{25 "}$ (Pieragnolo, 2011: 9). Fornoff y McClintock (1995) son los únicos críticos quienes lo mencionan, cuando aún poseía su primer título: Geografía del delirio. Doucet se refiere a este texto, junto a Aunque es de noche, como "poesía mística" (2009: 8).

Tampoco ha sido estudiado Érase una vez Al-Andalus (1992), texto editado en Infinita memoria de América. Poetiza la herencia árabe peninsular, a manera de "un retrato dramático y conmovedor de la condición fatal de los moros que vivían su historia de pre-exilio en la Iberia medieval" (Fornoff y McClintock 1995: 25). Durán (2003) documenta apenas notas sobre él.

Sobre Nocturnos de Julieta (1993) no se ha escrito nada. Doucet se refiere a este texto, solamente, como "poesía amorosa" (2009: 8).

Sobre la Enciclopedia de maravillas (1995), se encuentran los acercamientos críticos de Fornoff y McClintock (1995), von Mayer (1995), Durán (1995), Doucet (2009), expuestos a manera de prólogos para cada uno de los cuatro tomos ${ }^{26}$ de este texto; además de la tesis de maestría académica en literatura latinoamericana de Campos (2012). Sus argumentos se circunscriben a la importancia de la Enciclopedia de maravillas y su perspectiva metafísica u ontológica en medio de la poética de Albán.

Por su parte, Fornoff y McClintock establecen que, en la Enciclopedia de maravillas:

Cada poema intenta "definir" el objeto escogido como enfoque, pero las definiciones ejecutadas no son nada convencionales. Poema tras poema, objeto tras objeto rinde su trascendencia a una poderosa cosmovisión [...] El objeto estético no es de ninguna manera equivalente al objeto lingüístico. Objetivación dialéctica del cosmos, en tanto la estructura interior del yo lírico incursiona sobre la estructura exterior del cosmos, entre un objeto lingüístico y un objeto estético, donde aquel funciona como vasija del objeto estético, el cual transfigura el objeto lingüístico dentro de la matriz del sistema lingüístico (1995: 17 y 27)

Según estos críticos, este texto manifiesta una ductilidad de las imágenes y una cosmovisión reiterativa en la producción albaniana: "ausencia, olvido, memoria, el amor espiritual y erótico, impermanencia, tiempo, soledad, transparencia, la ansiedad humana, la ceniza, Dios, los elementos, y [...] el lenguaje (la palabra), el poeta, el poema, etc.” (1995: 33). La noción del hecho poético toma forma, precisamente, "cuando la palabra «desaparece» en un contexto trascendental mayor, cuando se realiza el acto de la poesía" (Albán 1995, citado en Fornoff y McClintock 1995: 36).

Estos dos autores, en síntesis, consideran la Enciclopedia de maravillas como un "proyecto audaz, más de mil poemas dirigidos a sondear el corazón numinoso de cualquier objeto" (Fornoff y McClintock 1995: 17); "la nueva obra maestra de la literatura latinoamericana", posterior al Boom en narrativa. Al respecto dicen:

Hace mucho se agotó el Boom de la novela. Luego vino la poesía. Desde 1979, la obra de Laureano Albán, desde Herencia del otoño, e incluso Viaje interminable, Biografías del terror, Geografía invisible de América, Todas las piedras del muro y Suma de claridades, constituye una explosión equivalente en poesía. Ahora con Enciclopedia de maravillas, Albán nos ha regalado la nueva obra maestra de la literatura latinoamericana (Fornoff y McClintock 1995: 36).

La Enciclopedia de maravillas se adscribe, según von Mayer (1995: 563), a la infinitud del 
pensamiento defendida por William Blake: "Si se abriesen las puertas de la percepción, cada cosa aparecería al hombre como es: infinita". Esta no es una "enciclopedia" desde el punto de vista cientificista-racional; al contrario, es un proyecto que conjuga la intuición intelectiva e intuición estética, "que describen el universo en toda su plenitud y complejidad [...] constituyéndose así en un conocimiento englobante del mundo" (von Mayer 1995: 564 y 565).

Desde este punto de partida, von Mayer expone que lo metafísico se evidencia en la poesía albaniana, en tanto se reflexiona sobre "los grandes enigmas de la existencia humana: Dios, la naturaleza, el hombre, la vida, la muerte y la trascendencia" (1997: 341). Solo a partir de las reflexiones metafísicas y ontológicas, y "una búsqueda constante hacia lo sublime, a través de la visión estética" (von Mayer, 1997: 341), Albán alcanza un grado de objetividad de las circunstancias del ser, pues:

En un mundo regido por la utilidad mercantilista y el pragmatismo, regido por los principios de la competencia y la productividad ganancial, Laureano Albán levanta su voz inmarcesible para recordarnos que no somos máquinas despersonalizadas, sino carne y espíritu, con la esperanza de un destino cósmico y sagrado (von Mayer, 1997: 346).

Esta iluminación cósmica y sagrada del mundo y las cosas se manifiesta, según Durán, desde "útiles caseros u objetos pequeños hasta sueños o mitos, vistos y descritos todos desde una nueva perspectiva, porque el poeta ha sabido establecer una relación íntima con su entorno" (1995, p. 1097). En su prólogo, este autor estudia y defiende las imágenes e intuiciones reveladoras de la Enciclopedia de maravillas y la obra de Albán, pues este, como "los grandes poetas [...] nos recuerdan insistentemente que el universo está poblado por muchas más cosas que las visibles, que más cosas bajo el sol que las que dicen las filosofías" (1995: 1097).

Doucet afirma que, desde 1984, Albán se ha dedicado a componer, de manera rigurosa y perseverante, la Enciclopedia de maravillas, "un hermoso caleidoscopio que permite enfrentar el destino de lo vivo, con un enorme gozo no exento de dolor humano [...] un universo- libro [...] donde cada objeto, cada animal, cada persona, cada valor, surge pleno de resonancias, frescos, recién creados ante nosotros" (2009: 8 y 9), tratando "de dar la definición ${ }^{27}$ poética que nos falta, del mundo que nos conforma y rodea [...] enganchándonos a la eternidad por unos instantes" (2009: 8 y 10).

Doucet caracteriza, al menos el IV tomo de la Enciclopedia de maravillas, como un espacio textual donde convergen la tradición y la originalidad, más que todo sobre el tratamiento del tema de la amada. Al respecto afirma:

Con originalidad, Laureano Albán retoma una
tradición poética europea que hunde sus raíces
en el medievo: los cancionere cuyos ejemplos
más conocidos los tenemos en Dante y Petrarca.
Estos poemarios tenían dos elementos básicos: eran
un diario y tenían como receptor a un personaje
femenino, la amada, que portaba todas las virtudes
del amor cortés [...] Como en los cancionere, la
mirada de la amada es determinante para la vida del
poeta [...] La naturaleza de la amada está próxima
a lo divino [...] Pero la originalidad de la amada en
el Tomo IV, reside en que ella es elemento activo en
el proceso de la creación [...] Yo no digo que este
nuevo tomo de la Enciclopedia, sea un cancionere
al uso, pero resulta delicioso constatar su función de
diario en numerosos ejemplos (2009: 9-10)

Por último, en su investigación, Campos (2012) analiza estética y hermenéuticamente una muestra textual de veinticuatro poemas de la Enciclopedia de maravillas, con el fin de identificar y delimitar, dentro de la manifestación de la poética trascendentalista de Albán, los motivos o las temáticas, los símbolos, los arquetipos y los mitos recurrentes como unidades ideológicas, relacionados con la vivencia del mysterium tremendum et fascinans de lo sagrado $^{28}$; así como evidenciar la importancia de - como afirma el investigador - este "aporte único cualitativa, cuantitativa y estilísticamente en la poesía universal" (Campos, 2012: 2).

Campos (2012) establece que la de Albán no es una "enciclopedia29" como todas las demás ${ }^{30}$. Por su perspectiva, forma y contenido, la Enciclopedia de maravillas supera la tradición del enciclopedismo francés del siglo XVIII y la Filosofía Occidental (Durand 1993), al proponer una dialéctica poética y subjetiva de 
la verdad, el mundo y la experiencia intuitiva de lo sagrado. Tradicionalmente, el vocablo "enciclopedia" pretende una fijación sígnica del mundo. No obstante, la Enciclopedia de maravillas, en tanto "enciclopedia", plantea un nuevo ordenamiento ${ }^{31} \mathrm{y}$ abordaje del mundo. Desde el título mismo de este texto albaniano, se inflige la tensión, la coniunctio, entre el lenguaje poético simbólico y lenguaje referencial científico de la comunicación operativa ${ }^{32}$ (Durand 1999), la cual desborda las virtualidades semánticas del lenguaje, la producción impulsiva e inconsciente de los símbolos, la materialización verbal de los arquetipos mediante lo imaginario y la organización, inclusive, de estos a través de mitos.

De ahí que la poiesis trascendentalista albaniana representa un acto nacido del mysterium fascinans, donde el sujeto lírico se acerca a lo numinoso, en un nivel interior, y se extasía con ello, por medio de la expresión lingüística de imágenes, metáforas, analogías y símbolos, los cuales resultan insuficientes, pero aproximativos a lo sagrado. En este sentido, el sujeto lírico ${ }^{33}$ de estos poemas presenta, en consecuencia, una actitud deísta ${ }^{34}$.

Campos (2012) observa que la mayoría de los poemas de la Enciclopedia de maravillas corresponde a un suprarrealismo, en términos de Otto (1925), al manifestar lo heterogéneo sagrado a través de motivos animales, vegetales, $\mathrm{y}$ otros asociados tanto con fenómenos y manifestaciones naturales; así como con instrumentos cotidianos, acciones concretas; seres divinos, mitológicos y humanos; e inclusive conceptos. Para el sujeto lírico, en cuanto homo religiosus, tales motivos le permiten ahondar en lo tremendo y fascinante, y establecer así un diálogo con la divinidad y una anamnesis (rememoración) de lo numinoso en su manifestación cósmica y microcósmica, mediante intervenciones simbólicas y el lenguaje poético.

Esta expresión de la experiencia de lo sagrado se logra a través de símbolos recurrentes como: el ángel, el sueño, el cielo, el mar, el fuego, el azul, la luz, el ala, el agua, el viento, la torre, el rastro, la noche, la niebla, la estrella y el espejo, entre otros presentes con menor frecuencia (el vuelo, la lejanía, el crepúsculo o la tarde, la aurora, el canto, la bandera, etc.).

Los susodichos símbolos y otros expresan los arquetipos de la tellus mater, el anciano sabio, el Adán u hombre original, la sombra, el soñador práctico, el ángel, la tribu, el animus y el anima, estos dos últimos entendidos tanto por Jung (1984) como por Bachelard (1997) ${ }^{35}$, a lo largo de la muestra poemática analizada.

A lo largo de la Enciclopedia de maravillas, se presenta, como médula, el arquetipo de Dios. Este arquetipo permite la integración de la psique, de todos los arquetipos mencionados anteriormente y la vita religiosa del sujeto lírico en tanto homo religiosus dentro de su sistema de valores místicos, su percepción trascendental de la vida y el cosmos, y la energeia simbólica y creadora de su palabra y sueños poéticos, ya que materializa la necesidad de comprender el universo, encontrar significado a todo cuanto ocurre y es, pues todo posee un propósito y una dirección al formar parte, justamente, del anima mundi.

En relación con la construcción mítica del imaginario del sujeto lírico, se identifica al menos la presencia de siete mitos: El relato bíblico del Génesis (1:26), en "El ala"; tanto en este último poema como en "El conjuro y "El lobo", se podría interpretar el mito hindú de Mahā-mâyâ ${ }^{36}$; en "El hacha" se observa el mito bíblico-religioso de la sacralización del trabajo y los instrumentos; en "El rastro", el mito de la vía regia; el mito griego del centauro Quirón y el caballo alado Pegaso en los poemas homónimos; y el mito del eterno retorno en "La tribu".

En síntesis, puede decirse que Fornoff y McClintock (1995), von Mayer (1995), Durán (1995), Doucet (2009) y Campos (2012) comparten el criterio sobre la presencia de un acercamiento simbólico, metafísico, existencial, cotidiano y revelador en el abordaje estético del cosmos y el lenguaje, en la Enciclopedia de maravillas.

Por el momento, El libro de los sabios que nunca han existido (2004), El peor de los pecados (2006), Ciento diez pensamientos $y$ 
un poema para Camila (2007) y Eros aeternus (2010) carecen de comentarios o estudios críticos.

\section{A manera de síntesis}

Habiendo establecido una revisión rigurosa sobre la literatura crítica con respecto a la producción poética albaniana, se concluye que los principales estudios abordan el corpus publicado entre 1966 y 1992, principalmente catorce de sus textos (Este hombre [1966], Las voces [1970], Solamérica [1972], Chile de pie en la sangre [1974], Vocear la luz [1977], Sonetos laborales [1977], Sonetos cotidianos [1978], Herencia del otoño [1979], La voz amenazada [1980], Geografía invisible de América [1982], Autorretrato y transfiguraciones [1983], Aunque es de noche [1983], Biografía del terror [1984] e Infinita memoria de América [1992]), sobre el cual se han establecido ubicaciones generacionales y categorizaciones. Se ha caracterizado esta producción poética como una poesía simbiótica de la realidad incierta, inmediata e históricosimbólica, cuyos principales atributos son:

a) El compromiso político-social e histórico, a la luz de la primera etapa de la producción albaniana (Monge 1984, Amoros 1987); donde se evalúa una visión ontológica, específicamente existencial, debido al acercamiento humanista y cotidiano. Este alcanza su mayor fuerza expresiva de la denuncia de los sistemas opresivos y dictatoriales en Biografía del terror. Esta perspectiva origina la inquietud y el estudio sistemático de Chaves (1987) sobre la isotopía existencial en Herencia del otoño.

b) La apertura hacia una comunicación poética de ruptura, en el marco de la poesía nacional, desde la década de 1970 hasta la actualidad, precisamente porque contraviene el concepto habituado de lo poético en el país durante este período.

c) La utilización y replanteamiento de un patrón retórico, a partir de un perfeccionamiento reflexivo y crítico de la expresión lírica, donde el objeto de estudio es, precisamente, el lenguaje poético, estético e ideológico. Tales principios se exponen en el Manifiesto trascendentalista.

d) El rescate de mitos cósmicos y simbólicos de las culturas americanas precolombinas, en el marco histórico de la Conquista; así como una revaloración de la herencia cultural árabe peninsular.

e) Un proyecto lírico sobre la temática de lo erótico, primero, en la contingencia (Monge 1984), con base en los "Sonetos conyugales", publicados en Sonetos cotidianos; y, segundo, desde el binomio erótico-religioso de una percepción mística (Rojas y Ovares 1995), en Aunque es de noche.

Durante este recorrido, se reconoce una visión hierática de lo metafísico en función de los enigmas humanos y de un diálogo con la divinidad en la producción albaniana, desde los primeros textos, expuesto con mayor ímpetu en Aunque es de noche a través de un panteísmo contrapuesto a sistemas de valores materialistas (Mora 1985).

Sobre su poética más representativa de corte metafísico y sagrado, Enciclopedia de maravillas, se puede afirmar que está dirigida a ser parte de un fin de mundo de los valores y las perspectivas materialistas, fenomenológicas de la realidad profana y circunstancialidades cotidianas, justamente porque ella abre de nuevo la permanencia e inmanencia de un sistema de valores éticos y metafísicos, los cuales enriquecen y transforman, estética y filosóficamente, las tragedias, sueños, vivencias, objetos, seres, conceptos y tramas cotidianos de la humanidad, dentro de las estructuras profundas de los arquetipos y mitos, la imaginación simbólica y la ensoñación poética, asociados con la vivencia de lo sagrado y su perennidad. Tomando en cuenta las palabras de Albán, Campos sintetiza, pues, que Enciclopedia de maravillas "es una especie de mística moderna, donde se entrecruza el tema contingente con la revelación" (Albán 2012, citado en Campos 2012: 362). 
Pieragnolo condensa, de la siguiente manera, las diferentes nociones sobre la polifacética y plurisignificativa producción poética albaniana:

Nei suoi versi si avverte la continua osmosi tra l'indubbia esistenza dell'anima e la sua dimensione assoluta, che alimenta un profondo desiderio di evidenze future e compiute. Una poesia che non può rinunciare a sensazioni e sentimenti, che lo percorre come stupefazione della materia e dell'incorporeità, come fervore che attraversa la scintilla originaria della vita. Coglie gli impulsi e le percezioni dal loro immaginifico spazio di effusione e vi si arrende con la libertà essenziale ad una rifondazione, ad un continuo concepimento delle parole e della loro melodia; un continuo scorrere che prende forza dall'enigma, una cognizione che si sostiene nella tensione e nell'attesa di una inafferrabile verità ${ }^{38}$. (2011: 11)

\section{Notas}

1. La producción poética de Albán es una de las más significativas de Costa Rica, publicada tanto en este último país, como en España, Italia, Jerusalén y Estados Unidos; traducida al inglés, italiano, francés, portugués, alemán y hebreo; así como también premiada en diez ocasiones, tanto en el nivel nacional como internacional.

2. Albán fue merecedor del máximo reconocimiento cultural y literario otorgado en Costa Rica: el Premio Magón 2006; y desde 1996 se encuentra nominado al Premio Nobel de Literatura.

3. Traducción: "uno de los poetas más importantes de la poesía hispanoamericana contemporánea"

4. Breto, a partir de su proceso de búsqueda sobre fuentes bibliográficas relacionadas con la obra poética de Albán, ha concluido que el investigador, con frecuencia, accede a "unas fuentes completamente mediatizadas en el aborrecimiento más visceral o en la adoración servil de la figura del escritor. Albán, un escritor polémico y aislado, desencadena por igual fobias y filias entre sus compañeros de generación, críticos y estudiosos, esa es la realidad" (2011-2012: 29).

5. Traducción: "poeta contracorriente, inagotable trascendentalista que desde hace cincuenta años llena sus páginas de transparencia, de imaginación inefable y destino por los elementos terrestres, en una época en la cual la poesía ha tratado de desprenderse de figuraciones y enfocarse en un lenguaje cotidiano, casi disgregándose en eso. Es raro encontrar un autor contemporáneo de este género". Cabe resaltar que esta afirmación de Pieragnolo (2011) se cimienta, casi literalmente, en las palabras de Fornoff y McClintock (1995: 19-20), las cuales se citarán, al final de este apartado, en la p. 10.

6. Dice von Mayer: "Desde muy joven, Laureano Albán se ha dedicado con absoluta pasión a la poesía, llegando a abordar una variedad temática impresionante. El poeta reflexiona sobre los grandes enigmas de la existencia: Dios, lo trascendente, la naturaleza, lo ontológico, la duda y la afirmación metafísicas, el misticismo, lo religioso; el amor, el dolor, la vida, la muerte, la contingencia y el drama humanos, lo cotidiano y lo perdurable, etc.” (2007: §2).

7. Con respecto a un texto inicial de Albán, titulado solamente "Poema", Jorge Debravo escribe en El Turrialbeño, desde una perspectiva notoriamente trascendentalista y con un tono prospectivo sobre la obra poética de aquel entonces estudiante de segundo año del Instituto de Educación Clodomiro Picado Twight:

El ensueño es una esencia inmaterial que vive indescifrada en todas las cosas. Sólo faltan unos ojos alegres y tristes a la vez, que lo sepan encontrar y que lo sepan comprender. Aquí en nuestro Colegio, a menudo se encuentra un brote luminoso de esa enredadera celeste: Un oído que ha podido descifrar el manto metafórico del alba o la gota de luz que habita en su propio corazón. Hoy presentamos a ustedes un pequeño poema del joven Laureano Albán Rivas, estudiante de segundo año, quien a xeces [sic] en sus horas tranquilas encuentra una chispa de dolor que de pronto se convierte en un arroyo.

La poesía es el lenguaje del alma, es la imagen de lo indefinible, parte integrante de todo hombre y de todo pueblo culto. (1957, abril 14: 4)

8. Falta considerar los prólogos de Albán para algunas obras producidas y editadas dentro del Círculo de Poetas Costarricenses; así como algunos poemas sueltos publicados en varias revistas; verbigracia: "Carta extraviada para Octavio Paz" (1979), en Cuadernos hispanoamericanos 343-345: 369-370. 
9. Este es el único artículo académico que Albán publicó de los redactados durante la realización de sus estudios de doctorado (1983-1986) en la State University of New York at Stony Brook.

10. El autor de este artículo se adscribe a esta categorización de Amoros (1987) sobre las etapas evolutivas de la producción de Albán, ya que este poeta evidencia cada vez más en sus textos un dominio y experimentación retóricos y simbólicos, una ampliación en los motivos y perspectivas por desarrollar, una precisión en cuanto a la construcción de imágenes y una apertura de significados, limpidez estilística y virtuosismo en cuanto al manejo de la corriente de consciencia, entre otros; todos ellos aspectos que bien se van fortaleciendo cronológicamente en su trayectoria literaria, desde 1961 hasta la actualidad, mediante su trabajo, dedicación y perseverancia poéticos.

11. Fornoff y McClintock aseguran: "Sería difícil imaginar la práctica particular de Albán sin las de Lorca, Salinas, Darío, Neruda, Paz, etc." (1995: 26). Con este aserto se sugieren las posibilidades de un estudio comparativo entre la obra de Albán y estos u otros poetas contemporáneos, de otras regiones y épocas.

12. Traducción: "después de la profunda crisis personal documentada en el libro de 1981 La voz amenazada, en la cual el poeta toma consciencia del fracaso de la ilusión juvenil, común para muchos otros escritores de su generación, de hacer de la poesía el instrumento transformador de la sociedad y del sentir humano, el desengaño y la frustración consecuente, encontrados de algún modo en una salvación ontológica de la palabra y la consciencia de la pérdida"

13. "Los cuatro escritores concuerdan en que no inventaron nada nuevo, y en el mismo libro así lo dejan claro. «Lo único que hicimos fue sistematizar lo que pensábamos en un libro y agregarle una pequeña antología poética de cada uno de nosotros; en ningún momento nos propusimos inventar algo nuevo», apunta Ronald Bonilla" (Rodríguez 2008: §9). Explica Albán: "Simplemente queríamos plasmar nuestro punto de vista y compartirlo" (Rodríguez 2008: §7). Agrega Dobles: "La poesía trascendentalista tiende a tratar más los temas del «espacio interior» del que hablaba Rilke, a hablar de todo aquello que es esencial” (Rodríguez 2008: §8).

14. Nótese que en las palabras de Boccanera (2004) y Corrales (2007) se inmiscuyen juicios subjetivos, los cuales parecen centrarse en la figura del poeta más que en un punto de vista objetivo y profundo sobre el proyecto ideológico expuesto por el Manifiesto trascendentalista. Sus juicios valorativos responden a lo colegido por Breto (2011-2012) en la nota 5.

15. Confirma Julieta Dobles (2008, citada en Rodríguez 2008: §6): "Laureano escribió el Manifiesto, y luego entre todos lo revisamos y lo firmamos".

16. "«Hablamos profusamente de la intuición como forma de conocimiento, de la imagen como instrumento estético-lingüístico, de superar la evidencia racionalista y limitada y media docena más de ideas», afirma Carlos Francisco Monge" (Rodríguez 2008: §10).

17. Traducción: "Concentró la atención en el resto de su continente agitado por el régimen autoritario, buscando responder a una necesidad personal y generacional. Participó del drama que dividió el continente y dedicó su obra a las víctimas de las dictaduras militares, que rigieron en Sur América hasta la mitad de los años setenta"

18. Doucet identifica el uso de legados culturales, literarios e históricos; verbigracia:

Mitos de creación como la creación del sol y el día por Viracocha [...] Modos de vida como las referencias a la base de sustento de los indios, la agricultura y a la peculiar visión de sus augures, de sus filósofos [...] Fundaciones de ciudades y nacimiento de culturas [...] Mito del Inkarri al que ya hemos aludido con anterioridad, creado en la época de la invasión española [...] Características de algunos dioses y rituales asociados a ellos [...] Incorporación de composiciones literarias indígenas como haillis, plegarias o himnos [...] O una plegaria prehispánica (2012: 6-8)

19. Traducción: "El viaje interminable describe el viaje del descubrimiento del nuevo mundo y la consecuente destrucción/construcción del continente con un lirismo épico, mientras que el sucesivo Geografía invisible de América prueba restituir la esencia espiritual de su ascendencia con la evocación elegíaca del pasado de las tres grandes civilizaciones precolombinas (aztecas, mayas e incas) para alcanzar la construcción mitopoética de la realidad hispanoamericana, la participación de ambas culturas de hispanismo"

20. Traducción: “un viaje a través del propio país, los objetos, las respuestas, los susurros, los estímulos 
de un nuevo y recíproco redescubrimiento, al lado de la exaltación de las imágenes y las metáforas, en una continua fusión y conversión de los elementos naturales para la construcción de un diverso cosmos donde reconocerse"

21. Traducción: “Trece cánticos que resumen una denuncia plena de modernidad, el ansia contemporánea de todos los hombres y la antigua pregunta, que espera la luz en medio del hombre universal; en estos versos no hay un optimismo ciego, ni desesperación, porque la noche es símbolo de una continua búsqueda del diálogo y la confrontación con Dios"

22. Breto computa sesenta y tres víctimas y tres abortos: treinta y cuatro chilenos, dieciséis argentinos, doce uruguayos y un español; ellos corresponden a: "mujeres, mujeres embarazadas, niños, niños recién nacidos, ancianos, familias, e incluso una comunidad de campesinos; las edades de las víctimas oscilan entre los quince a los setenta y cinco años. Y pertenecen a todos los grupos sociales, desde médicos, campesinos y albañiles hasta burócratas, políticos y profesores" (2011-2012: 12).

23. Con respecto a este punto, Breto difiere, pues piensa que, en este texto albaniano: "la poesía funciona como resistencia ante el drama, acerca al lector un pasado de necesaria recuperación y conocimiento, señala claramente a las víctimas, pero también avergüenza a sus verdugos" (2011-2012: 6).

24. Traducción: "publicados en una singular edición en cuatro idiomas (español, inglés, francés y hebreo), como homenaje del pueblo costarricense al de Israel"

25. Traducción: "en la cual el poeta recupera la intensa influencia y la emoción de los lugares de su infancia y su familia originaria"

26. Los tres primeros tomos de la Enciclopedia de maravillas fueron publicados en 1995 y el cuarto en 2010, por la Internacional Poetry Forum, los cuales configuran una unidad textual catalogada como: "La primera enciclopedia escrita totalmente en poesía, en la historia de la humanidad" (1995: portada del libro). En la portada del IV tomo, la leyenda versa: "La única enciclopedia escrita totalmente en poesía en la historia de la literatura".

27. En 1967, el poeta cubano Eliseo Diego publicó Muestrario del mundo o Libro de las maravillas de Boloña. En este poemario, pretendió iluminar "cada signo del zodíaco, cada estación del año, cada herramienta del hombre, etc" (Diego 1986: 84), a partir de la fascinación que le motivó "el catálogo de los tipos de letras, grabados y viñetas de la Imprenta de don José Severino Boloña” (Diego 1986: 84), publicado en La Habana en 1836. Sobre este último, dice el mismo Diego:

Era más que un simple catálogo. En páginas de diversos colores -rosadas, verdes, amarillas- se desplegaban los tipos de letras a lo largo de una aparente Historia de la Imprenta. Venían luego las viñetas de las cuatro estaciones del año, grabados de todas las cosas y criaturas imaginables, los doce signos del zodíaco y como gran final, una danza macabra de esquelas mortuorias. El catálogo quedaba convertido en un pequeño acertijo del universo (1986: 84).

En comparación con la Enciclopedia de maravillas, el texto de Diego se limita a fortalecer la relación ilustración-texto, donde ambas textualidades se complementan. La segunda, claramente, aparece posterior a la primera y en función de esta. En el texto de Albán, la definición poética del mundo no se restringe a ilustrar el universo, sino que trasciende sus significaciones hacia lo metafísico y místico, e inclusive reinventándolo. El texto de Diego, por lo tanto, pareciera ser, en la literatura latinoamericana, un antecedente más del objetivo estético de la Enciclopedia de maravillas, pero disímil en cuanto a la perspectiva poética. Cabría también la posibilidad de establecer un estudio comparativo entre ambos textos.

28. Para tal análisis se emplearon, como aproximaciones teóricas, el concepto de imaginación simbólica según Gilbert Durand (1971, 1982, 1993); el símbolo de acuerdo con Durand (1971), Jean Chevalier y Alain Gheerbrant (1988), y Mircea Eliade (1981); los arquetipos y el símbolo arquetípico con base en los principios epistemológicos de Carl Jung (1923, 1984); el mito según Eliade (1964, 1991); la noción de lo sagrado a partir de Eliade (1981) y Rudolf Otto (1925); así como la idea de facultad intuitiva considerando algunos criterios de este último autor.

29. La palabra "enciclopedia" se construye morfológicamente a partir de las voces griegas:

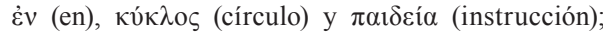
literalmente, significa: "educación redondeada" o "conocimiento general". Toda enciclopedia, desde el punto de vista cultural e histórico del enciclopedismo francés del siglo XVIII, corresponde a un conjunto orgánico, en el cual se 
recogen y divulgan informaciones especializadas y correspondientes a diversos campos del saber y de las actividades humanas, dando preeminencia a la conceptualización (RAE 2001) y los datos que no podrían ser hallados con facilidad.

30. Campos (2012) establece un cuadro de similitudes y diferencias tanto formales como de contenido entre una enciclopedia tradicional y la Enciclopedia de maravillas. Consúltense las pp. 70 y 71 de dicho estudio.

31. Como afirma Durand (1971), paradójicamente la imaginación simbólica es expresa a través de una letra sistemática. La contemplación del sujeto lírico de la Enciclopedia de maravillas y la enunciación de sus verdades son ordenadas por medio de una tipologización según el abecedario español, aunque esta última no signifique ningún riesgo o restricción para aquellas.

32. Sobre este tipo de lenguaje, refieren Albán et al: "El lenguaje llamado directo en su precisión tiene sus límites; en su exactitud semántica denota su ineficiencia para expresar los significados evolucionantes de la realidad" (1977: 60).

33. El sujeto lírico en estos poemas de la Enciclopedia de maravillas constituye un homo religiosus (Eliade 1964, 1981), ya que "cree que lo sagrado se le ha dado a conocer, se le ha aparecido, se le ha manifestado, durante la experiencia religiosa" (Chinchilla 2010: 98), a través de algunos de los seres, objetos y materialidades que contempla, utiliza o acciones que realiza. Lo sagrado, para aquel sujeto, corresponde, ergo, a una modalidad de ser en el mundo, pues, como dice Eliade: "Cualquiera que sea el contexto histórico en que esté inmerso, el homo religiosus cree siempre que existe una realidad absoluta, lo sagrado, que trasciende este mundo, pero que se manifiesta en él y, por eso mismo, lo santifica y lo hace real" (1981: 170).

34. Entiéndase por deísmo, el reconocimiento de un dios como autor de la naturaleza y el universo (RAE 2001). En la Enciclopedia de maravillas, se presenta una noción filosófica de Dios (Ferrater 1993); es decir, el Ser es visto como lo absoluto, fundamento de las existencias, causa primera, finalidad suprema, lo trascendente, entre otros. Dios es el Ente supremo, “es lo que está más allá de todo ser" (Ferrater 1993: 118).

35. Tómese en cuenta que Bachelard (2002) maneja el concepto de animus y anima junguianos de una forma ligeramente desviada, pues para Jung (1984) el animus corresponde a la parte masculina de la psique de la mujer; mientras el anima, al complemento femenino del varón.

36. De acuerdo con el hinduismo, Mahā-mâyâ corresponde a la Gran Ilusión. "Mâyâ", en sánscrito, corresponde al arte, el poder o la virtud mágica extraordinaria o prodigiosa. El Mahāmâyâ constituye, por tanto, un modo de designar el encubrimiento del Brahman (el Creador del universo) y la operación de su Śakti (poder, fuerza o energía particular de un dios). Según los hindúes (Schuhmacher y Woerner 1993), el hombre necesita de la Śakti para captar el aspecto trascendente de un dios o lo sagrado. Con base en la filosofía vedânta, únicamente aquello inmutable y eterno, como el Espíritu, merece el nombre de lo sagrado. Todo cuanto se encuentra sujeto a incesantes cambios por decaimiento y diferenciación y, por lo tanto, tiene principio y fin, es considerado como mâyâ: ilusión. Esta es la ficción que origina la aparición ilusoria o personificación irreal de los objetos mundanos. Ella corresponde al poder cósmico que posibilita la existencia fenomenológica y las percepciones de la realidad. En consecuencia, el universo objetivo o la naturaleza se consideran una ilusión.

37. Como se ha demostrado, este tratamiento trascendental de los objetos cotidianos, por ejemplo, no es exclusivo de la Enciclopedia de maravillas. Ya había sido trabajada por Albán en Sonetos laborales (1977) y Sonetos cotidianos (1978). Puede considerarse este tratamiento, pues, como una tendencia y perspectiva continua en la producción poética de este autor costarricense. Este tratamiento poético que Albán les da a los objetos cotidianos ya se pueden rastrear en la poesía latinoamericana del siglo XX, específicamente en los textos de Gabriela Mistral, quien pretende poetizar el mundo a través de "las cosas [...] simples, elementales, toscas", verbigracia: "un puñado de polvo o [...] un tazón roto" (Oviedo 2001: 268). Según Oviedo, este fue el afán estético de la poeta chilena. Por su parte, Pablo Neruda organiza metódicamente, en sus Odas elementales (1954), Nuevas odas elementales (1956) y Tercer libro de las odas (1957), un proyecto estético que busca la trascendencia de los objetos cotidianos a través de la poesía, propuesto como un nuevo ordenamiento del mundo a partir de los elementos que lo componen. En este sentido, afirma Oviedo: "Neruda quiso «poetizar» el mundo, nombrar cada una de sus cosas, de la $\mathrm{A}$ a la $\mathrm{Z}$, como quien compusiese una enciclopedia lírica" (2001: 349). En estas odas, Neruda desea "continuar con su proyecto de verbalizar la totalidad del mundo, convertirlo en un inagotable acto de lenguaje: si se piensa bien, 
estas odas (que se disponen alfabéticamente, desde la «Oda al aire» y la «Oda al vino») son como un inventario de la realidad, terrestre, de las infinitas cosas que hacen la existencia posible y que, por su humildad, no habían ingresado a la poesía" (Oviedo 2001: 373). Laureano Albán lleva este afán poético hasta un nivel más claramente enciclopédico, pero integrado con verdades metafísicas, cósmicas y místicas de mayor complejidad subjetiva, asociadas con las vivencias de lo sagrado, los mitos y los arquetipos. Con base en lo susodicho, se sugiere la posibilidad de un estudio comparativo entre la obra de Albán y Neruda.

38. Traducción: En sus poemas hay una interacción constante entre la existencia indudable del alma y su dimensión absoluta, que se alimenta de un profundo deseo de evidente futuro y realización. Se trata de una poesía que no puede renunciar a las sensaciones y sentimientos que la recorren como un asunto de asombro ante la materia y la incorporeidad, como el fervor que se ejecuta a través de la chispa original de la vida. Apreciar los impulsos y la percepción de su espacio imaginario de efusión y sin renunciar a la libertad esencial ante una refundación, ante una continua concepción de las palabras y su melodía; ante un flujo continuo que tiene la fuerza del enigma, un conocimiento que se sostiene en la tensión y en la expectativa de una verdad difícil de alcanzar.

\section{Referencias bibliográficas}

Albán, L. 1986. Biografías del terror. San José: Editorial Costa Rica.

1995. Enciclopedia de maravillas. Tomos I, II y III. Pittsburg, Estados Unidos: International Poetry Forum.

2010. Enciclopedia de maravillas. Tomos IV. Pittsburg, Estados Unidos: International Poetry Forum.

2011. Poesie imperdonabili. Italia: Passigli.

Albán, L.etal. 1977. Manifiesto trascendentalista. San José: Editorial Costa Rica.
Amoros, A. 1987. "Una metafísica del mito originario: La poesía de Laureano Albán". En Revista Iberoamericana 138-139 (enero-junio): 353-361.

Azofeifa, I. 5 de mayo 1980. "El premio Adonáis para Laureano Albán”. En La Nación: 5B.

Bachelard, G. 1997. El agua y los sueños. México: Fondo de Cultura Económica.

2002. La poética de la ensoñación. México: Fondo de Cultura Económica.

Baeza, A. 1978. Evolución de la poesía costarricense. San José: Editorial Costa Rica.

16 de marzo 1980. "El otoño de España, inspiración para un premio «Adonáis» de poesía". En La Nación, Áncora: 4.

Barahona, L. 2011. Lo real y lo imaginario. San José: Editorial Costa Rica.

Berroa, R. 1983. "Laureano Albán: un poeta con duende". En Revista Iberoamericana 123124 (49): 577-588.

Boccanera, J. 2004. Voces tatuadas. Crónica de la poesía costarricense 1970-2004. San José: Perro Azul.

Bonilla, A. 1981. Historia de la literatura costarricense. San José: STVDIVM.

Breto, J. 2011-2012. Biografías del terror: Laureano Albán y el deber del llanto. Trabajo de fin de maestría. Universidad Complutense.

Camacho, J. 1987. "Aproximaciones críticas a un estudio de la metáfora en la poesía costarricense: Indicación metodológica". En Revista Iberoamericana 138-139 (enero-junio): 363-376. 
Campos, R. 2012. De la permanencia de lo sagrado en la Enciclopedia de maravillas de Laureano Albán. Tesis de maestría. Universidad de Costa Rica.

Chase, A. 1986. Poesía y gráfica contemporánea de Costa Rica. San José: Editorial Costa Rica.

Chaves, I. 1987. La interoceptividad: Paradigma fundamental en el universo semántico de Herencia del otoño. Tesis de licenciatura. Universidad de Costa Rica.

Chávez, R. 1984. "Una visión de la literatura turrialbeña a partir de la generación del 60”. En Káñina 1-2 (8): 29-31.

1985. "Los nuevos en la literatura turrialbeña”. En Káñina 1 (9): 75-79.

Chen, J. 2000. VII Congreso Costarricense de Filología, Lingüistica y Literatura Dr. Jack Wilson Kilburn. San José, Costa Rica: Editorial Universidad de Costa Rica.

Chevalier, J. y A. Gheerbrant. 1988. Diccionario de los símbolos. Barcelona: Herder.

Chinchilla, K. 2010. Conociendo la mitología. San José: Editorial de la Universidad de Costa Rica.

Corrales, A. 2007. "Jorge Debravo: El hermano mayor”. En Comunicación 16: 27-33.

Cros, E. 25 de noviembre 1984. "Canto al dolor humano". En La Nación, Áncora: 1-3.

Debravo, J. 14 de abril 1957. "Un poema de Laureano Albán Rivas, alumno de II Año de nuestro Instituto de Educación”. En $E l$ Turrialbeño 2 (39): 4.

Diego, E. 1986. Entre la dicha y la tiniebla: Antología poética (1949- 1985). México: Fondo de Cultura Económica.
Doucet, M. 2009. "Prólogo". En Albán (2010): 8-10.

2012. “Geografía invisible de América (mayas, nahuas, quechuas): multiculturalidad e identidades en el universo poético de Laureano Albán". Ponencia pronunciada en el VIII Congreso Internacional Literatura, Memoria e Imaginación de Latinoamérica y el Caribe (por los derroteros de la oralidad y la escritura). Lima, Perú.

Durán, J. 1995. “La poesía de Laureano Albán: Desde la esmeralda ceñida de su patria hasta el altar de la tierra". En Albán (1995): 1083-1097.

2003. "La poesía de Laureano Albán: Desde la esmeralda ceñida de su patria hasta el altar de la tierra". En Senderos de identidad: 167-188.

Durand, G. 1971. La imaginación simbólica. Buenos Aires: Amorrortu.

1982. Las estructuras antropológicas de lo imaginario. Madrid: Taurus.

1993. De la mitocrítica al mitoanálisis. Figuras míticas y aspectos de la obra. Barcelona: Anthropos.

1999. Ciencia del hombre y tradición. Barcelona: Paidós.

Duverrán, C. 1973. Poesía contemporánea de Costa Rica. San José: Editorial Costa Rica.

Eliade, M. 1981. Lo sagrado y lo profano. Barcelona: Labor, S.A.

1964. Tratado de historia de las religiones. Madrid: Cristiandad.

1991. Mitos y realidades. Barcelona: Colección Labor. 
Fajardo, M. 16 de marzo 1982. "Una lectura para Herencia del otoño de Laureano Albán". En La República: 9.

Fernández, G. 02 de septiembre 2012. “El antilirismo costarricense". En La Nación. Recuperado de http://www.nacion. com/2012-09-02/Ancora/El-antilirismocostarricen se.aspx

Ferrater, J. 1993. Diccionario de Filosofía abreviado. Buenos Aires: Sudamericana.

Fornoff, F. y S. McClintock. 1987. "La poética de ausencia en Laureano Albán". En Revista Iberoamericana 138-139 (enero-junio): 331-351.

1995. "Después del boom, una explosión de poesía”. En Albán (1995): 17-37.

Greimas, A. 1976. Semántica estructural. Madrid: Gredos.

Jara, E. 24 de marzo 1980. "Los versos de Albán”. En La Nación: 15A.

Jung, C. 1984. Arquetipos e inconsciente colectivo. Barcelona: Paidós. 1923. Psychological Types. Nueva York: Harcourt y Brace.

Monge, C. 1981. "Los dos lados del fuego". En Repertorio Americano 4: 1-5.

1984. La imagen separada. San José: Instituto del Libro, Ministerio de Cultura, Juventud y Deportes.

1987. "La escritura: Pasión de la historia. La poesía contemporánea de Costa Rica". Revista Iberoamericana 138-139 (enerojunio): 303-323.
1992. Antología crítica de la poesía de Costa Rica. San José: Editorial de la Universidad de Costa Rica.

1998. Costa Rica: Poesía escogida. San José: EDUCA.

1999. La rama de fresno. Heredia: Editorial de la Universidad Nacional.

Mora, A. 1985. "La poesía religiosa de Laureano Albán”. En Káñina 1 (9): 81-86.

Otto, R. 1925. Lo santo. Lo racional y lo irracional en la idea de Dios. Madrid: Revista de Occidente.

Oviedo, J. 2001. Historia de la literatura hispanoamericana. Posmodernismo, vanguardia, regionalismo. Madrid: Alianza Editorial.

Picado, M. 1983. Literatura, ideología, crítica. San José: Editorial Costa Rica.

Pieragnolo, T. 2011. "Prefazione”. En Albán (2011): 5-12.

Quesada, Á. 2000. Breve historia de la literatura costarricense. San José: Porvenir.

Real Academia Española. 2001. Diccionario de la lengua española. Recuperado de http:// www.rae.es/rae.html

Rodríguez, F. 2006. “La formación discursiva trascendentalista en la poesía costarricense contemporánea". En Filología y Lingüistica 2 (32): 107-119.

Rodríguez, N. 27 de enero 2008. "Treinta años a cuatro voces”. En La Nación. Recuperado de http://wvw.nacion.com/ancora/2008/ enero/27/ancora1393347.html. 
Rojas, M. y F. Ovares. 1995. 100 años de literatura costarricense. San José: Farben.

Rosales, L. 18 de mayo 1980. "Herencia del otoño: Un libro de poesía especializada". En La Nación: 5B.

Salas, E. 2000. Poesía turrialbeña 1960-1999. San José: Editorial de la Universidad Estatal a Distancia.

Sánchez, C. 02 de febrero 2011. “Apuntes para una postvanguardia y transvanguardia en Costa Rica". En Los 7 ahorcados. Recuperado de http://los7ahorcados. blogspot.com/20 11/02/apuntes-parauna-postvanguardia-y.html.

Schuhmacher, S. y G. Woerner. 1993. Diccionario de la sabiduría oriental. Barcelona: Paidós.
Soto, R. 2009. Pingüinos, camellosyornitorrincos. Sobre literatura y otras especies. San José: Editorial de la Universidad Estatal a Distancia.

Tovar, E. 8 de junio 1980. "Laureano Albán: Un poeta embriagado por el otoño". En $L a$ Nación: 5B.

Von Mayer, P. 1995. "Enciclopedia de maravillas, o la experiencia del asombro inagotable". En Albán (1995): 563-574.

1997. "La sublime transparencia: Poesía mística de Laureano Albán”. En Chen (ed): 341-349.

21 de enero 2007. "Laureano Albán, premio «Magón» 2006”. En La Nación. Recuperado de http://wvw. nacion.com/an cora/2007/enero/21/ paginasflotantes96153 6.html. 